\title{
Characterization of the Interactive Effects of Labile and Recalcitrant Organic Matter on Microbial Growth and Metabolism
}

\author{
Lauren N. M. Quigley', Abigail Edwards' ${ }^{1}$, Andrew D. Steen ${ }^{2}$ and Alison Buchan ${ }^{1 *}$ \\ ${ }^{1}$ Department of Microbiology, The University of Tennessee, Knoxville, Knoxville, TN, United States, ${ }^{2}$ Department of Earth \\ and Planetary Sciences, The University of Tennessee, Knoxville, Knoxville, TN, United States
}

OPEN ACCESS

Edited by:

Jarone Pinhassi,

Linnaeus University, Sweden

Reviewed by:

Sonja Kristine Fagervold,

UMS2348 Observatoire

Océanologique de Banyuls-sur-Mer

(OOB), France

Carina Bunse,

Helmholtz-Institut für Funktionelle

Marine Biodiversität (HIFMB),

Germany

*Correspondence:

Alison Buchan

abuchan@utk.edu

Specialty section:

This article was submitted to

Aquatic Microbiology,

a section of the journal

Frontiers in Microbiology

Received: 28 September 2018

Accepted: 26 February 2019

Published: 19 March 2019

Citation:

Quigley LNM, Edwards A, Steen AD and Buchan A (2019) Characterization of the Interactive Effects of Labile and Recalcitrant Organic Matter on Microbial Growth and Metabolism.

Front. Microbiol. 10:493. doi: 10.3389/fmicb.2019.00493
Geochemical models typically represent organic matter $(\mathrm{OM})$ as consisting of multiple, independent pools of compounds, each accessed by microorganisms at different rates. However, recent findings indicate that organic compounds can interact within microbial metabolisms. The relevance of interactive effects within marine systems is debated and a mechanistic understanding of its complexities, including microbe-substrate relationships, is lacking. As a first step toward uncovering mediating processes, the interactive effects of distinct pools of $\mathrm{OM}$ on the growth and respiration of marine bacteria, individual strains and a simple, constructed community of Roseobacter lineage members were tested. Isolates were provided with natural organic matter (NOM) and different concentrations (1, 4, 40, $400 \mu \mathrm{M}-\mathrm{C}$ ) and forms of labile OM (acetate, casamino acids, tryptone, coumarate). The microbial response to the mixed substrate regimes was assessed using viable counts and respiration in two separate experiments. Two marine bacteria and a six-member constructed community were assayed with these experiments. Both synergistic and antagonistic growth responses were evident for all strains, but all were transient. The specific substrate conditions promoting a response, and the direction of that response, varied amongst species. These findings indicate that the substrate conditions that result in OM interactive effects are both transient and species-specific and thus influenced by both the composition and metabolic potential of a microbial community.

Keywords: interactive effects, terrestrially derived, dissolved organic matter, Roseobacter, species-specificity, community interactions

\section{INTRODUCTION}

$2.5 \mathrm{Tg}-\mathrm{C}$ of terrestrially derived dissolved organic matter (t-DOM) flows through riverine systems annually, where the microbial community preferentially utilizes the more labile components (Vannote et al., 1980; Hedges et al., 1997). This process leads to the development of an increasingly recalcitrant organic carbon pool, enriched in aromatic moieties, as headwaters move toward coastal margins (Sun et al., 1997; Mannino and Harvey, 2000). Most chemical tracers diagnostic of t-DOM (e.g., lignin-derived phenols) are removed before reaching the open oceans (Hedges et al., 1997; Osburn et al., 2016), suggesting that this material is transformed in land-sea margins. Microbial 
degradation clearly contributes to the disappearance of t-DOM in these dynamic aquatic systems (Ward et al., 2013).

It has recently been postulated that biological interactions with different pools of organic compounds drive OM transformations in aquatic environments (Guenet et al., 2010; Bianchi, 2011). This hypothesis has been framed within the concept of the priming effect (PE). Under the broadest definition of the term, PE occurs when the addition of a labile carbon substrate and/or nutrients alters the rate at which microorganisms degrade recalcitrant organic carbon (Kuzyakov et al., 2000). These interactive effects are non-additive and can be either positive (synergistic) or negative (antagonistic). The microbial response may rely critically on the concentration and molecular composition of organic compounds, experimental timescale, nutrient status and microbial community composition (Blagodatskaya and Kuzyakov, 2008; Catalán et al., 2015; Steen et al., 2016). PE has long been recognized as an important factor in soil OM turnover. However, this framework has only recently been applied to aquatic systems where its present role is enigmatic (Jenkinson et al., 1985; Guenet et al., 2010; Bianchi, 2011). Bengtsson et al. (2018) posit the variable PE responses reported in the aquatic sciences literature suggests $\mathrm{OM}$ interactive effects are likely context dependent. As such, an improved mechanistic understanding of the microbial response to mixed OM pools is needed to enable predictive modeling of $\mathrm{OM}$ fate in various environments (Bengtsson et al., 2018).

The salt marshes fringing the coast of the Southeastern United States, and the microbial communities residing within these systems, provide a relevant system in which to study factors relevant to $\mathrm{OM}$ interactions and microbial processing. The rivers flowing through these marshes carry $400-2300 \mu \mathrm{M}-\mathrm{C}$ dissolved organic carbon (DOC), approximately $75 \%$ of which is terrestrially derived (Alberts and Takács, 1999). Additionally, these salt marshes are among the most productive ecosystems on Earth, with net primary production rates ranging from 0.2 to $2.25 \mathrm{~kg} \mathrm{C} \mathrm{m}^{-2}$ year $^{-1}$ (Wiegart and Freeman, 1990; Hyndes et al., 2014). Within these systems, autochtonous labile inputs, from salt marsh vegetation and phytoplankton, mix with the recalcitrant t-DOM imported by riverine systems at the land-sea interface, setting the stage for OM interactions that may stimulate resident coastal microbial communities to degrade recalcitrant t-DOM. Potential for positive, albeit transient, priming of Southeastern United States coastal microbial communities has been demonstrated (Steen et al., 2016). However, the specific factors that control $\mathrm{OM}$ interactive effects at the level of individual environmentally relevant bacteria and/or communities of bacteria, have not been elucidated.

Members of the Roseobacter clade of marine bacteria are among the most numerically abundant and active members of the coastal bacterial communities, and several representative strains have been isolated from Southeastern United States estuaries (e.g., Gonzalez et al., 1997; González et al., 1999; Slightom and Buchan, 2009). Success of the lineage has largely been attributed to metabolic diversity, including growth on a wide range of plantderived aromatic compounds characteristic of t-DOM (Moran et al., 2007; Mou et al., 2008; Medeiros et al., 2017; Sipler et al., 2017). Growth assays are supported by genome analyses which indicate Roseobacters often possess multiple catabolic pathways for aromatic compound degradation (Newton et al., 2010). Given their abundance, metabolic activity, and ability to oxidize plantderived aromatic monomers, members of the Roseobacter clade are ideal lab cultivars to examine how representative members of the estuarine community may undergo interactive effects to degrade t-DOM.

Here, we assess the influence of labile carbon concentration and chemical identity on the growth dynamics and respiration of representative marine bacteria provided an environmentally relevant and natural source of organic matter (NOM). The NOM utilized in these experiments was derived from the Suwannee River, a Southeastern United States blackwater river, and is enriched in aromatic moieties of lignin origin (Her et al., 2003). We used monocultures of two coastal Roseobacter species, Sagittula stellata E-37 and Citreicella sp. SE45, both of which were isolated from Southeastern coastal waters and have demonstrated abilities to degrade plant-derived recalcitrant compounds (Gonzalez et al., 1997; Frank, 2016; Chua, 2018). We constructed community of six coastal bacteria that included these two strains community as well as four other Roseobacter strains selected based on the number (1-6) and types of aromatic carbon catabolism pathways present in their genomes (Table 1). In this study, 16 labile organic matter (LOM) conditions were tested in a fully factorial experiment. Four substrates, ranging from simple to chemically complex (sodium acetate, coumarate, casamino acids + tryptophan, and tryptone, in order of increasing chemical complexity) at four concentrations ( 1,4 , 40 , and $400 \mu \mathrm{M}$-C; Table 2) were provided as growth substrates for monocultures of S. stellata and Citreicella sp. SE45 and the six-member constructed community. Sources of LOM were chosen to represent a gradient of chemical complexities that are differentially processed by microbes: sodium acetate and casamino acids + tryptophan are likely shunted directly into central metabolism; tryptone is a mixture of oligo-peptides, many of which require initial extracellular enzymatic breakdown before products are transported across the cell membrane and enter central metabolism; and coumarate, an aromatic monomer derived from lignin (Hedges et al., 1988). Cleavage of the aromatic ring requires specific pathways that are found in a limited number of microbes and are most often subject to catabolite repression (Dal et al., 2002; Mazzoli et al., 2007). Of the six bacterial isolates tested, only S. stellata and Citreicella sp. SE45 possess the ability use coumarate as a sole carbon source.

\section{MATERIALS AND METHODS}

\section{Strains, Media, and Growth Conditions}

Sagittula stellata sp. E-37, Citreicella sp. SE45, Phaeobacter sp. Y4I, Roseovarius nubinhibens ISM, Sulfitobacter sp. EE-36, and Sulfitobacter sp. NAS-14.1 were routinely grown on an aromatic basal medium (ABM) containing per liter $8.7 \mathrm{mM}$ $\mathrm{KCl}, 8.7 \mathrm{mM} \mathrm{CaCl}_{2}, 43.5 \mathrm{mM} \mathrm{MgSO}_{4}$, and $174 \mathrm{mM} \mathrm{NaCl}$ with $225 \mu \mathrm{M} \mathrm{K}_{2} \mathrm{HPO}_{4}, 13.35 \mathrm{mM} \mathrm{NH}_{4} \mathrm{Cl}, 71 \mathrm{mM}$ Tris- $\mathrm{HCl}$ (pH 7.5), $68 \mu \mathrm{M}$ Fe-EDTA, trace metals $(7.8492 \mathrm{mM}$ Nitroloacetic acid, $0.5325 \mathrm{mM} \mathrm{MnSO}_{4}{ }^{*} \mathrm{H}_{2} \mathrm{O}, 0.4203 \mathrm{mM} \mathrm{CoCl}_{2}{ }^{*} 6 \mathrm{H}_{2} \mathrm{O}, 0.3478 \mathrm{mM}$ 
TABLE 1 | Genomic evidence for aromatic carbon catabolism pathways and prophages present in Roseobacter strains used in this study.

\begin{tabular}{|c|c|c|c|c|c|c|}
\hline \multirow[b]{2}{*}{ Aromatic catabolism pathway } & \multicolumn{6}{|c|}{ Isolate } \\
\hline & $\begin{array}{l}\text { Citreicella } \\
\text { sp. SE45 }\end{array}$ & $\begin{array}{c}\text { Phaeobacter } \\
\text { sp. Y4I }\end{array}$ & $\begin{array}{c}\text { Roseovarius } \\
\text { nubinhibens ISM }\end{array}$ & $\begin{array}{c}\text { Sagittula } \\
\text { stellata E-37 }\end{array}$ & $\begin{array}{c}\text { Sulfitobacter } \\
\text { sp. EE-36 }\end{array}$ & $\begin{array}{l}\text { Sulfitobacter } \\
\text { sp. NAS-14.1 }\end{array}$ \\
\hline$\beta$-ketoadipate (protocatechuate) & + & + & + & + & + & + \\
\hline Gentisate & + & - & - & + & - & - \\
\hline Benzoyl-CoA & - & - & - & + & - & - \\
\hline Phenylacetic acid & + & + & - & + & + & + \\
\hline Homoprotocatechuate & - & + & - & + & - & - \\
\hline Homogentisate & + & + & - & + & - & - \\
\hline Predicted prophage-like elements ${ }^{c}$ & 2 & 4 & 0 & 5 & 0 & 0 \\
\hline
\end{tabular}

${ }^{a}$ Genomic data derived from Chua (2018). ${ }^{b}$ Genomic data derived from Buchan and González (2010) and Newton et al. (2010). 'Determined using VirSorter (Roux et al., 2015).

$\mathrm{ZnSO}_{4} * 7 \mathrm{H}_{2} \mathrm{O}, 0.0376 \mathrm{mM} \mathrm{CuSO}, 0.1052 \mathrm{mM} \mathrm{NiCl}_{2} * 6 \mathrm{H}_{2} 0$, $1.1565 \mathrm{mM} \mathrm{Na}_{2} \mathrm{SeO}_{3}, 0.4134 \mathrm{mM} \mathrm{Na}_{2} \mathrm{MoO}_{4} * 2 \mathrm{H}_{2} \mathrm{O}, 0.3259 \mathrm{mM}$ $\mathrm{Na}_{2} \mathrm{WO}_{4} * 2 \mathrm{H}_{2} \mathrm{O}, 0.2463 \mathrm{mM} \mathrm{Na}_{2} \mathrm{SiO}_{3} * 9 \mathrm{H}_{2} \mathrm{O}$ ) and trace vitamins (0.0020\% vitamin $\mathrm{H}$ [Biotin)], $0.0020 \%$ folic acid, $0.0100 \%$ pyridoxine- $\mathrm{HCl}$ (B6), $0.0050 \%$ riboflavin (B2), 0.0050\% thimaine (B1), $0.0050 \%$ nicotinc acid, $0.0050 \%$ pantothenic acid (B5), $0.0001 \%$ cyanocobalamin (B12), 0.0050\% p-aminobenzoic acid). These strains were routinely passaged on ABM containing $10 \mathrm{mM}$ sodium acetate. Four of these strains (E-37, SE45, Y4I, and EE36) were isolated from Southeastern US coastal waters, while NAS-14.1 was isolated from North Atlantic off-shore waters and ISM from the Caribbean Sea (Buchan et al., 2000; Cude et al., 2012). The bacteria were routinely cultured at $30^{\circ} \mathrm{C}$, shaking, in the dark. This temperature condition is nominally representative of Southeastern US salt marshes which are tidally influenced and where average water temperatures are close to $30^{\circ} \mathrm{C}$ from June through September (The Southeast Regional Climate Center, University of North Carolina, Chapel Hill, NC). Suwannee River natural organic matter (NOM), obtained from the International Humic Substance Society (IHSS, St. Paul, $\mathrm{MN}$ ) was used as a representative t-DOM. This material is a discipline standard for natural organicmatter (Her et al., 2003).

TABLE 2 | Organic carbon composition of the comparative treatments groups used to test for interactive effects.

\begin{tabular}{|c|c|c|c|c|}
\hline $\begin{array}{l}\text { Comparative } \\
\text { treatment } \\
\text { group }\end{array}$ & $\mathrm{NoC}^{\mathrm{a}}$ & LOM $^{\mathrm{b}}$ & NOM $^{c}$ & $\operatorname{Mix}^{d}$ \\
\hline $00 \mu \mathrm{M}-\mathrm{C}$ & No OC added & $400 \mu \mathrm{M}-\mathrm{C}$ LOM & $2 \mathrm{mM}-\mathrm{C}$ NOM & $\begin{array}{l}400 \mu \mathrm{M}-\mathrm{C} \text { LOM (16.67\%) } \\
2 \mathrm{mM}-\mathrm{C} \text { NOM (83.33\%) }\end{array}$ \\
\hline $40 \mu \mathrm{M}-\mathrm{C}$ & No OC added & $40 \mu \mathrm{M}-\mathrm{C}$ LOM & $2 \mathrm{mM}-\mathrm{C}$ NOM & $\begin{array}{l}40 \mu \mathrm{M}-\mathrm{C} \text { LOM (1.67\%) } \\
2 \mathrm{mM}-\mathrm{C} \text { NOM (98.33\%) }\end{array}$ \\
\hline $4 \mu \mathrm{M}-\mathrm{C}$ & No OC added & $4 \mu \mathrm{M}-\mathrm{C}$ LOM & $2 \mathrm{mM}-\mathrm{C}$ NOM & $\begin{array}{l}4 \mu \mathrm{M}-\mathrm{C} \text { LOM }(0.17 \%) \\
2 \mathrm{mM}-\mathrm{C} \text { NOM }(99.83 \%)\end{array}$ \\
\hline $1 \mu \mathrm{M}-\mathrm{C}$ & No OC added & $1 \mu \mathrm{M}-\mathrm{C}$ LOM & $2 \mathrm{mM}-\mathrm{C}$ NOM & $\begin{array}{l}1 \mu \mathrm{M}-\mathrm{C} \text { LOM (0.04\%) } \\
2 \mathrm{mM}-\mathrm{C} \text { NOM (99.96\%) }\end{array}$ \\
\hline \multicolumn{5}{|c|}{$\begin{array}{l}\text { aNo carbon added (base medium), tests for microbial activity in the } \\
\text { absence of added organic carbon. }{ }^{b} \text { Labile organic matter, (acetate, casamino } \\
\text { acids + tryptophan, coumarate, or tryptone) added at one of four concentrations. } \\
{ }^{c} \text { Natural organic matter (recalcitrant organic matter). }{ }^{d} \text { Mixed substrate treatments. } \\
\text { Values in parentheses indicate the relative contribution of LOM and NOM to } \\
\text { the total organic carbon pool. To assess interactivity in mix treatments, those } \\
\text { data are compared to composite data which is the sum of results of the LOM } \\
\text { and NOM treatments. }\end{array}$} \\
\hline
\end{tabular}

Incubations occurred in the dark as the aromatic moieties in NOM are sensitive to photodegradation. NOM is provided in lyophilized form from IHSS and was suspended in Milli-Q water and $0.22 \mu \mathrm{m}$ filter-sterilized prior to addition to the medium. NOM was held at a constant concentration of $2 \mathrm{mM}-\mathrm{C}$ for all experiments. ${ }^{13} \mathrm{C}$ NMR estimates of carbon distribution provided by IHSS show that Suwannee NOM comprised of roughly $25 \%$ aromatic residues.

Four different forms of LOM (sodium acetate, casamino acids + tryptophan, coumarate, and tryptone) were added at four concentrations (400, 40, 4, and $1 \mu \mathrm{M}-\mathrm{C})$ using $\mathrm{ABM}$ as the base medium. Cultures were grown for 14 days in the dark at $30^{\circ} \mathrm{C}$, with shaking. Substrate concentrations were selected after a preliminary experimentation using a LOM concentration gradient of $400 \mu \mathrm{M}-\mathrm{C}$ to $20 \mathrm{nM}-\mathrm{C}$. All glassware used was combusted at $450^{\circ} \mathrm{C}$ for at least $4 \mathrm{~h}$ to remove trace organic carbon. All experiments utilized cultures preconditioned on 2 mM-C $p$-hydroxybenzoic acid to match the carbon concentration of the Suwannee River NOM utilized in the mesocosms. The growth rates of all strains on this substrate at this concentration are comparable and mid-exponential phase cultures were used as inoculum at volumes of 10-100 $\mu \mathrm{l}$. As cells were not washed prior to transfer to fresh media, there may have been some modest carryover of $p$-hydroxybenzoate $(<2 \mu \mathrm{M})$. Nonetheless, carryover would have been consistent across treatments for a given strain or the six-member community and comparisons were always made to composite data (NOM plus LOM alone controls) which would have the same amount of carryover. Viable cell density experiments were carried out in volumes of $10 \mathrm{~mL}$ while respirometer incubations were in $125 \mathrm{~mL}$ volumes.

\section{Experimental Treatments}

All experiments assessed interactive effects of OM by comparing viable cell density or respiration in a treatment containing both labile and recalcitrant OM to the sum of growth or respiration in treatments containing only one of those carbon sources. There were a total of four treatments: NoC (no carbon addition control), LOM (labile organic matter alone), NOM (Suwannee River natural organic matter alone), and "mix" (LOM + NOM treatments) (Table 2). The NoC controls lacked both LOM and 
NOM, serving as a control for bacterial growth on medium components. The LOM treatment consisted of LOM under the same conditions as the corresponding mix treatment. The NOM treatment contained $2 \mathrm{mM}-\mathrm{C}$ Suwannee River NOM as the sole carbon source. The mix treatment had both $2 \mathrm{mM}-\mathrm{C}$ NOM and one of four concentrations of the different LOMs. Composite was calculated by adding the response of LOM alone and NOM alone. The microbial seeding density for all experiments was $\sim 1 \times 10^{4}$ cells $\mathrm{mL}^{-1}$, cell densities are reported in figures and tables. For the constructed community inoculum, equal representation of each strain was targeted.

For each treatment, viable cell abundance and community composition were measured. As we were motivated to understand the ability of different $\mathrm{OM}$ mixtures to support the growth of marine bacteria, viable counts were monitored rather than direct microscopic counts or DNA-based approaches, which generally do not readily distinguish between living and dead cells. Viable counts have the additional advantage over direct counts that it is easy to distinguish between individual Roseobacter strains (see below). Viable counts were obtained by serial dilution in ABM. Dilutions were plated on YTSS agar, a complex medium (per liter: $5 \mathrm{~g}$ yeast extract, $2.5 \mathrm{~g}$ tryptone and $15 \mathrm{~g}$ sea salts) and incubated in the dark at $30^{\circ} \mathrm{C}$. Single strain plates were incubated for 2 days, while constructed community plates were incubated for 4 days in order to allow the development of identifying pigment. Plates with $30-300$ colonies were counted. Cultures were spot-checked for cell clumping by microscopy and none was evident (Supplementary Figure S1).

Due to the impraticality of obtaining all of the necessary samples from a single set of experimental samples, two parallel sets of the same experiment were performed. A set of incubations for viable counts was first performed and the results from those incubations were used to inform the conditions selected for incubation in a respirometer. For the cell abundance and community composition experiment, culture aliquots were collected on days $0,1,2,4,7,10$, and 14 . Community composition was determined by colony morphology, as each strain of Roseobacter in the community had a unique, readily identifiable, colony morphology (Supplementary Figure S2). Respiration was monitored in a separate set of microcosms using a Micro-Oxymax respirometer (Columbus Instruments, Columbus, $\mathrm{OH}$, United States), in which cumulative $\mathrm{CO}_{2}$ production was measured by infrared absorbance continuously throughout a shorter (7 days) incubation period.

\section{Data Analysis}

To assess interactive effects of mixed substrate treatments, the sum of the viable cell density or $\mathrm{CO}_{2}$ production in the LOM and NOM treatments was calculated and termed "composite," which represents the case in which growth on LOM and NOM are independent. The timing, extent and nature (synergistic or antagonistic) of interactive responses was determined through comparison of the resulting composite data and that from the mixed substrate treatments.

All data analysis was performed using the $\mathrm{R}$ statistical platform and visualized using the ggplot2 package (Wickham, 2009; R Core team, 2015). Raw data and scripts are posted at http://github.com/lnmquigley/roseo_priming_2018. Cell densities were log-transformed and sub-setted by day. For each day, a three-way ANOVA was performed to determine whether differences in cell densities were being driven by treatment, concentration or source of LOM. Because the experimental design was unbalanced, two three-way ANOVAs were performed on the final time point in the respirometer incubations in order to determine the factors influencing $\mathrm{CO}_{2}$ accumulation. Additionally, rates were calculated during exponential $\mathrm{CO}_{2}$ production, and three-way ANOVAs were employed to identify factors influencing the rate of $\mathrm{CO}_{2}$ production. For all ANOVAs, Fisher's least significant difference was used as a post hoc test and $p$-values were adjusted to correct for the false discovery rate using the Benjamini-Hochberg correction (Benjamini and Hochberg, 1995).

Community composition was determined by visually identifying constructed community members based on their distinct colony morphologies (Supplementary Figure S2). In order to calculate $\alpha$ diversity in the constructed community experiments, Shannon entropy was calculated for each culture, which was then exponentially transformed into Hill numbers, also known as effective species number (Jost, 2007). A three-way ANOVA was performed to determine the relationship between effective species number and treatment, concentration and source of LOM. The $p$-values obtained from the Fisher's least significant difference were adjusted using the Benjamini-Hochberg correction to account for multiple comparisons. A Bray-Curtis dissimilarity matrix was calculated using all constructed community cultures for each day. In order to determine sources of variation (treatment, concentration, and/or source of LOM) within the Bray-Curtis dissimilarity matrix, a permutational MANOVA was employed using the Adonis function in the $\mathrm{R}$ package vegan (Oksanen et al., 2017).

\section{RESULTS}

\section{Substrate Preferences Vary Between Individual Strains}

To assess the extent to which each LOM type and concentration could support the growth of the tested coastal marine bacteria, we monitored viable counts of monocultures of E-37 and SE45 as a function of OM treatment. Viable cell abundances for SE45 and E-37 increased two to three orders of magnitude within the first $24 \mathrm{~h}$ of incubation, depending on the concentration of LOM provided (Figure 1). In both strains, LOM type and concentration interacted significantly to drive cell densities at each time point (three-way ANOVA, $n=5, p<0.001$, Supplementary Tables S1, S2), with the single exception of E-37 on day 14 (Supplementary Table S2). For all four LOM types, the two lowest concentrations of LOM $(1$ and $4 \mu \mathrm{M})$ did not support reliable growth, relative to No C added controls, of either of the two monocultures over the course of the experiment (Figure 1). With the exception of E-37 provided $40 \mu \mathrm{M}$ tryptone, neither of the two bacterial isolates showed consistently robust growth at $40 \mu \mathrm{M}$ with the remaining LOM substrates (Figure 1). For all LOM types, the highest concentration of labile carbon 


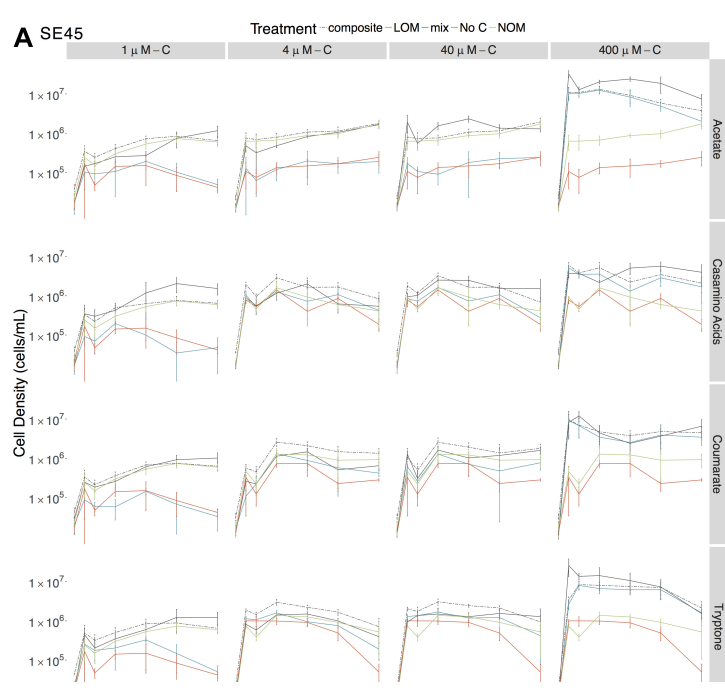

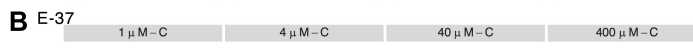

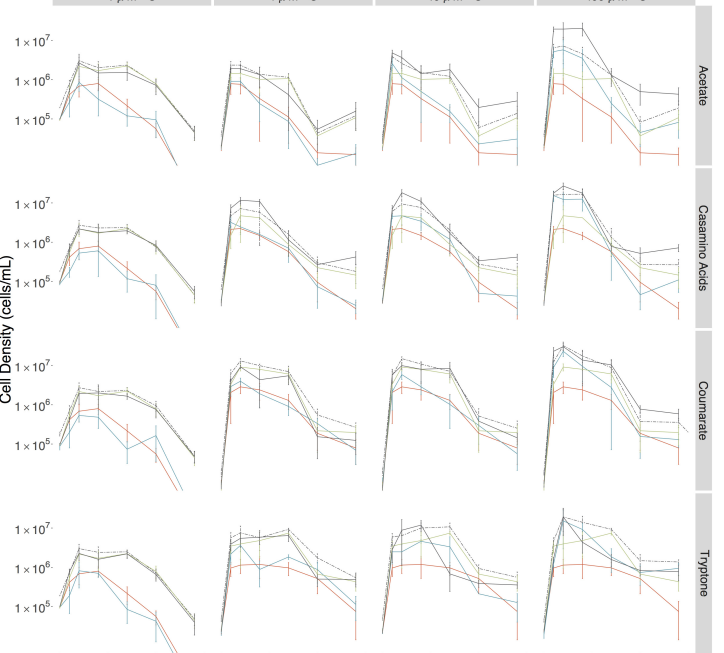

$\begin{aligned} & \text { C Constructed Community } \\ & 1 \mu \mathrm{M}-\mathrm{C}\end{aligned} \quad \underset{4 \mu \mathrm{M}-\mathrm{C}}{40 \mu \mathrm{M}-\mathrm{C}} \quad 400 \mu \mathrm{M}-\mathrm{C}$
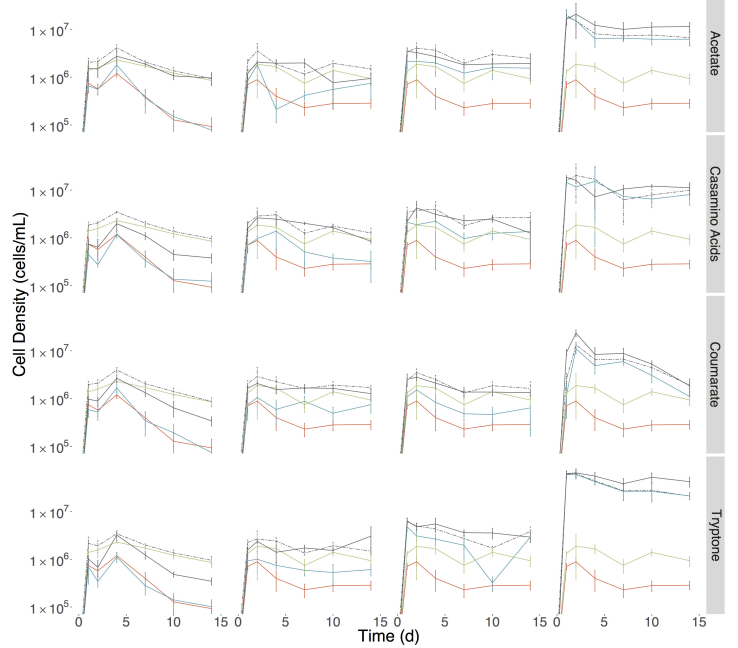

FIGURE 1 | Viable counts for monocultures of (A) SE45, (B) E-37, and (C) constructed communities in composite (dashed line), LOM alone (blue line),

(Continued)
FIGURE 1 | Continued

mix (black line), No Carbon control (red line), and NOM alone control (green line) treatments. The composite treatment is the sum of results of the LOM and NOM treatments. Points represent the mean $(n=3-5)$; error bars represent one standard deviation from the mean. Seeding densities for SE45, E-37 and six-member constructed community were $1.51 \times 10^{4} \mathrm{CFU} / \mathrm{mL}$ $\left( \pm 5.1 \times 10^{3}\right), 4.23 \times 10^{4} \mathrm{CFU} / \mathrm{mL}\left( \pm 9 \times 10^{3}\right)$ and $7.01 \times 10^{3} \mathrm{CFU} / \mathrm{mL}$ $\left( \pm 2.6 \times 10^{3}\right)$, respectively. Significant interactive effect for individual timepoints are shown in Supplementary Figure S3 (E-37 and SE45) and Supplementary Figure $\mathbf{S 4}$ (constructed community).

(400 $\mu \mathrm{M})$ showed significantly enhanced growth of both the strains (7-15 times greater than No C). A general trend emerged for all cultures in which cell viability increased rapidly at the start of the experiment and was followed by a decline beginning at day 4 or later. SE45 saw declines ranging from 73 to $85 \%$ of viable cells in all of the $400 \mu \mathrm{M}$ LOM alone treatments. However, viable cells remained significantly (at least threefold) higher than No C controls throughout the course of the experiment (Figure 1). In contrast, E-37 demonstrated a more rapid decline in viability. By the end of the 14-day incubation period, strain E-37 had $<1 \%$ of maximum viable cells remaining in the LOM alone treatments provided $400 \mu \mathrm{M}-\mathrm{C}$ acetate, casamino acids and coumarate. Furthermore, viable counts in those cultures were indistinguishable from No C controls by day 10 or earlier. Viable count data indicate that both monocultures and the community are able to use a small fraction of NOM-derived carbon in the absence of any LOM (Figure 1).

Each strain demonstrated unique and apparent preferences for the four different LOM types. Given the boom and bust growth dynamics described above, we focused on maximal viable counts within the first $48 \mathrm{~h}$ of the experiment for all LOM types provided at the highest concentration $(400 \mu \mathrm{M})$. E-37 reached the highest cell densities on coumarate, nearly 10 -fold higher viable counts compared to No C controls $\left(2.3 \times 10^{7} \pm 6.28 \times 10^{6}\right.$ vs. $2.86 \times 10^{6} \pm 9.34 \times 10^{5} \mathrm{CFU} / \mathrm{mL}$ ) and lowest on acetate $\left(5.18 \times 10^{6} \pm 1.58 \times 10^{6} \mathrm{CFU} / \mathrm{mL}\right)$. E-37 grew equally well on casamino acids and tryptone. SE45 growth was equivalent on all substrates except casamino acids, for which its viable counts were $\sim 50 \%$ of those grown on the other three substrates within the first few days of the experiment (Figure 1).

\section{Individual Strains Show Differential Responses to Mixed Organic Matter Treatments}

For the mixed substrate experiments, NOM was held at a constant concentration of $2 \mathrm{mM}-\mathrm{C}$, consistent with OC concentrations in Georgia coastal estuaries (Alberts and Takács, 1999). To assess interactive growth responses, mixed substrate treatments (mix), which included a source of LOM and NOM in the same treatment, were compared to a composite class of data: the additive response of the LOM alone and NOM alone treatments. This allowed us to assess synergistic or antagonistic interactions of LOM and NOM on bacterial growth in the mixed treatments.

The individual strains displayed differing response to the various treatments. SE45 reached the highest viable cell densities 
in the mix treatments $(\mathrm{LOM}+\mathrm{NOM})$ with the highest LOM concentrations ( $400 \mu \mathrm{M}-\mathrm{C}$; Figure 1). Final viable cell densities increased with increasing LOM concentrations. While E-37 viable cell densities generally tracked with LOM concentrations, the differences in maximum cell densities across LOM type and concentration were less than an order of magnitude, compared to on average 10-fold difference in SE45 treatments between 400 $\mu \mathrm{M}-\mathrm{C}$ and the lower concentrations.

While both strains displayed a significant growth response to the majority $(\geq 75 \%)$ of mixed-substrate treatments, the effect was always transient (Figure 1 and Table 3). Both synergistic (positive) and antagonistic (negative) responses were observed, and the responses were species-specific. A significant synergistic response was seen for SE45 on all four LOM substrates at the highest concentration (400 $\mu \mathrm{M}-\mathrm{C})$. However, this was displayed at different time points for the different LOMs (Supplementary Figure S3 and Table 3). Conversely, antagonistic interactions (i.e., composite cell densities significantly higher than those in mixtures) were observed for all LOM types at $4 \mu \mathrm{M}-\mathrm{C}$ (Supplementary Figure S3 and Table 3) with this strain. Inconsistent trends were observed in other LOM concentration

TABLE 3 | Probability values ${ }^{\text {a }}$ for monoculture interactive effects experiments shown in Figure $\mathbf{1}$ for strains SE45 and E-37.

\begin{tabular}{|c|c|c|c|c|}
\hline \multirow[b]{2}{*}{ LOM source } & \multicolumn{4}{|c|}{ LOM concentration ${ }^{b}$} \\
\hline & $1 \mu \mathrm{M}-\mathrm{C}$ & $4 \mu \mathrm{M}-\mathrm{C}$ & $40 \mu \mathrm{M}-\mathrm{C}$ & $400 \mu \mathrm{M}-\mathrm{C}$ \\
\hline \multirow[t]{6}{*}{ Acetate } & SE45 & SE45 & SE45 & SE45 \\
\hline & Days $1,4,7$ & Days 2, 4 & Days $2,4,7$ & Days $2,7,10$ \\
\hline & $p<0.05$ & $p<0.05$ & $p<0.05$ & $p<0.001$ \\
\hline & E-37 & E-37 & E-37 & E-37 \\
\hline & Day 1 & Days 7 & Days 10, 14 & Days $1,2,4,10,14$ \\
\hline & $p<0.05$ & $p<0.001$ & $p<0.05$ & $p<0.01$ \\
\hline \multirow[t]{6}{*}{ Casamino acids } & SE45 & SE45 & $\underline{\text { SE } 45}$ & SE45 \\
\hline & Day 10,14 & Days $1,2,10$ & Day 1 & Day $4 p<0.001$ \\
\hline & $p<0.05$ & $p<0.05$ & $p<0.05$ & Day $7 p<0.001$ \\
\hline & E-37 & $\mathrm{E}-37$ & $\mathrm{E}-37$ & $\mathrm{E}-37$ \\
\hline & No significant & Days $1,4,14$ & Days 2, 14 & Day 14 \\
\hline & difference & $p<0.05$ & $p<0.05$ & $p<0.05$ \\
\hline \multirow[t]{6}{*}{ Coumarate } & SE45 & SE45 & SE45 & SE45 \\
\hline & $\begin{array}{c}\text { No significant } \\
\text { difference }\end{array}$ & Days $\overline{1,2,4}, 10$ & Days 2, 7 & Day 2 \\
\hline & & $p<0.05$ & $p<0.05$ & $p<0.05$ \\
\hline & $\underline{E-37}$ & $\underline{E-37}$ & E-37 & $\underline{E-37}$ \\
\hline & Day 1 & Day $1,4,10,14$ & Day 10 & Days 1,10 \\
\hline & $p<0.05$ & $p<0.05$ & $p<0.05$ & $p<0.05$ \\
\hline \multirow[t]{6}{*}{ Tryptone } & $\underline{\text { SE45 }}$ & SE45 & $\underline{\text { SE45 }}$ & $\underline{\text { SE45 }}$ \\
\hline & $\begin{array}{l}\text { No significant } \\
\text { difference }\end{array}$ & Days 1, 2, 4 & Days 1, 4, 7 & Day 1 \\
\hline & & $p<0.01$ & $p<0.05$ & $p<0.001$ \\
\hline & E-37 & $\mathrm{E}-37$ & E-37 & $\mathrm{E}-37$ \\
\hline & No significant & Day 10 & Days $1,7,10$ & Days $1,4,7,14$ \\
\hline & & $p<0.01$ & $p<0.05$ & $p<0.05$ \\
\hline
\end{tabular}

${ }^{a}$ For each day, a three-way ANOVA was performed to determine whether differences in cell densities were being driven by treatment, concentration or source of LOM. p-values are adjusted to correct for the false discovery rate using the Benjamini Hochberg correction. b Days listed are days in which there was a significant difference between the composite and mixed treatments. Each strain is underlined and situated directly above the experimental days and their probability values. $p$-values for synergistic interactive effects are bolded and the corresponding table cell is shaded gray; $p$-values for antagonistic interactive effects are italicized. treatments. E-37 also displayed a significant response to all four LOM substrates at the highest concentrations, but the effect was negative on one substrate: tryptone (Supplementary Figure S3 and Table 3). Growth of E-37 was negatively influenced at some point during the experiment for all concentrations of tryptone, except the lowest $(1 \mu \mathrm{M}-\mathrm{C})$. While a synergistic response was observed with coumarate at the highest concentration, antagonistic responses were observed with this substrate at the three lower concentrations. When E-37 displayed a significant growth response on casamino acids, it was always synergistic.

Due to the differential growth responses of the two strains to different concentrations of casamino acids, additional experiments were performed to monitor respiration at all concentrations of this LOM. Respiration assays were also performed on cultures provided acetate and coumarate at the highest LOM concentration ( $400 \mu \mathrm{M}-\mathrm{C}$ ) to provide comparative information on the influence of different chemical compositions of LOM to microbial metabolism. These assays were run for 7 days as the majority of culture growth from the previous experiment occurred within the first few days of incubation (Figure 1). As a result of automated sampling, the respiration data provided higher temporal resolution. However, due to the sensitive nature of the probes it was neither possible to agitate the culture vessels nor take samples for viable counts throughout the course of the incubation, as was done for the previously described experiment. Instead, viable counts were performed for the seeding inoculums and each vessel at the final (day 7) time points (Supplementary Table S3). These values likely do not reflect the maximum viability of these cultures which is anticipated to have occurred earlier in the experiment, consistent with what was observed for the first experiment (see Figure 1). Indeed, it is likely that by day 7 , cultures would be experiencing a decline in cell viability for several of the treatments.

The response by SE45 to mixed conditions when measured via respiration matched the results found in the initial experiment for 1 and $400 \mu \mathrm{M}-\mathrm{C}$ casamino acids (Figure 2). However, mixed and composite $\mathrm{CO}_{2}$ production were statistically indistinguishable from each other with cultures provided $400 \mu \mathrm{M}-\mathrm{C}$ coumarate and $40 \mu \mathrm{M}-\mathrm{C}$ casamino acids (Figure 2 and Table 4), despite the fact that these treatments exhibited significant synergistic and antagonistic responses, respectively, when assayed by viable count during the initial experiment (Figure 1). $\mathrm{CO}_{2}$ production in NOM alone treatments was statistically indistinguishable from mixed OM treatments when SE45 was provided low concentrations of casamino acids as well as the highest $(1,4$, and $400 \mu \mathrm{M}$; Student's $t$-test $p>0.05)$. However, $\mathrm{CO}_{2}$ production on NOM was significantly lower than the mixed treatments at $40 \mu \mathrm{M}$-C casamino acids (Student's $t$-test $p<0.05$ ) and acetate and coumarate at $400 \mu \mathrm{M}-\mathrm{C}$ (Student's $t$-test $p<0.05$ ). At low concentrations of casamino acids, the mixed and composite treatments of E-37 were statistically indistinguishable according to the ANOVA model used (Table 4). The low concentration mixed treatments for E-37 all had significantly higher rates of $\mathrm{CO}_{2}$ production ( $\sim 2$ - to 10 -fold) than their corresponding LOM alone treatments (Supplementary Tables S5-S7). E-37 produced a synergistic response when stimulated with $400 \mu \mathrm{M}-\mathrm{C}$ acetate, casamino acids and coumarate, yielding cumulative $\mathrm{CO}_{2}$ 
A Low Concentrations of casamino acids Treatment-composite-mix $1 \mu \mathrm{M}-\mathrm{C}$ $4 \mu \mathrm{M}-\mathrm{C}$ $40 \mu \mathrm{M}-\mathrm{C}$

750

500
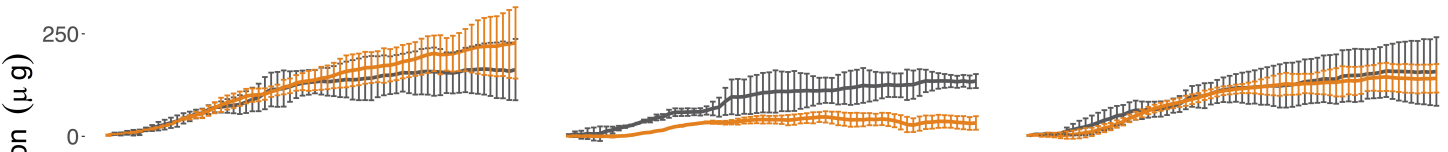

ํำ 750

500

$+$

250

0 .
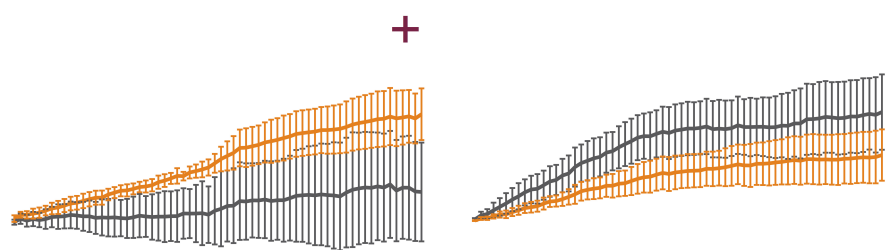

2

4

6

0

2

6

Casamino Acids

$+$
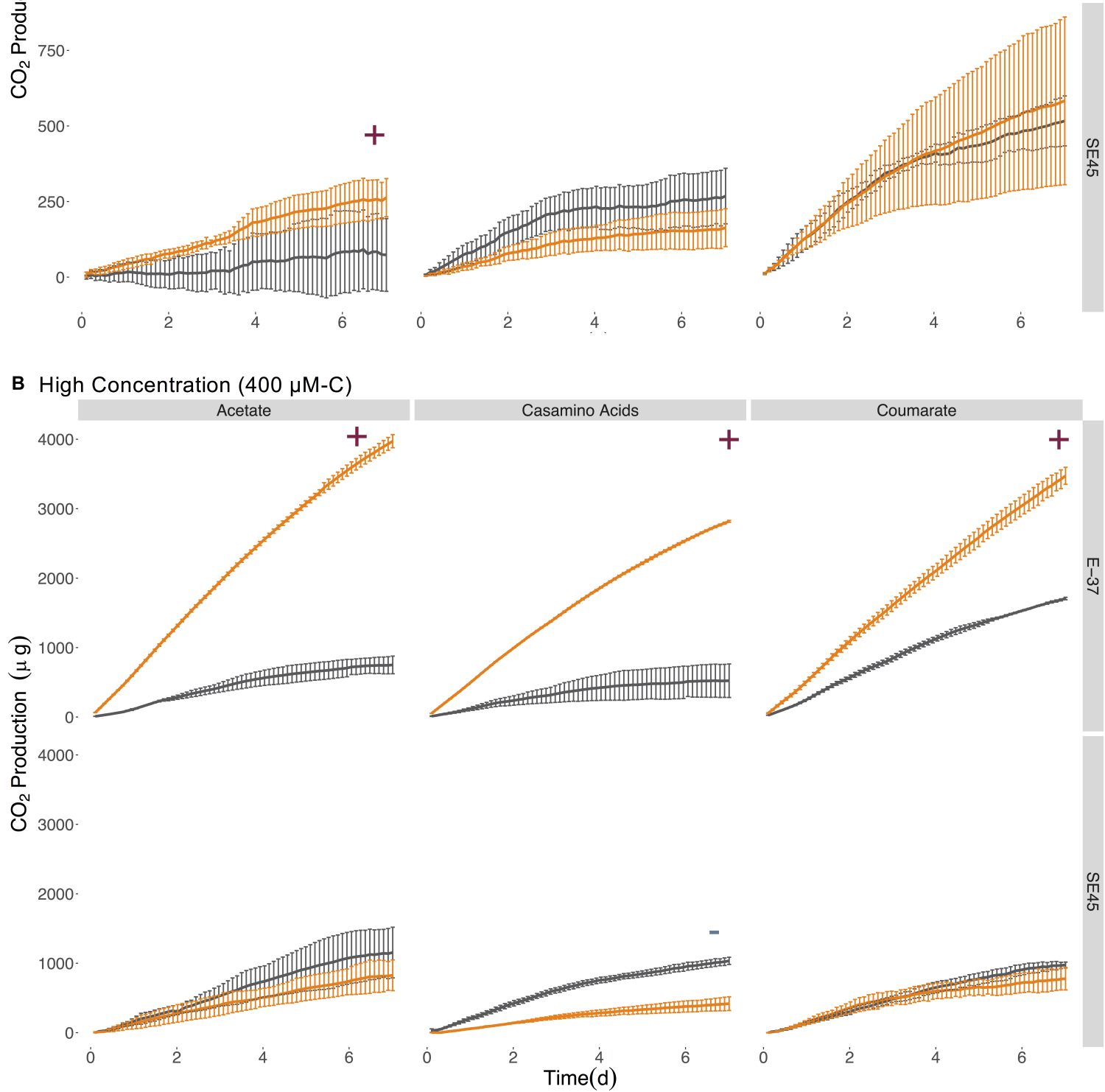

B High Concentration $(400 \mu \mathrm{M}-\mathrm{C})$

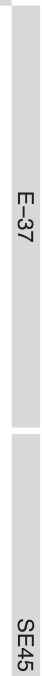

FIGURE 2 | Cumulative $\mathrm{CO}_{2}$ production from SE45 and E-37 monocultures when provided (A) low concentrations of casamino acids and (B) high concentrations $(400 \mu \mathrm{M}-\mathrm{C})$ of acetate, casamino acids, and coumarate. Composite data (sum of LOM and NOM treatments) are shown in gray; mixed substrate data in orange. The average of the No C control was subtracted from all replicates. Points represent the mean $(n=2-3)$; error bars represent one standard deviation from the mean. Red plus signs indicate a significant synergistic interactive effect $(p<0.05)$, blue minus signs indicate an antagonistic interactive effect $(p<0.05)$. The seeding densities for SE45 and E-37 were $3.05 \times 10^{4} \mathrm{CFU} / \mathrm{mL}\left( \pm 7.97 \times 10^{3}\right), 1.43 \times 10^{4} \mathrm{CFU} / \mathrm{mL}\left( \pm 4.71 \times 10^{3}\right)$, respectively. Final cumulative $\mathrm{CO}_{2}$ produced for all control treatments is shown in Supplementary Table S4. 
production values that were twofold to fivefold higher than the corresponding composite data (the sum of the NoC and LOM alone treatments) and rates that were 3 - to 10 -fold higher than the corresponding LOM alone data (Figure 2B, Table 4, and Supplementary Tables S5-S7).

\section{Constructed Community Displays Similar Dynamics to Single Strains Under Mixed OM Conditions}

Given the differential response of individual strains to homogenous and mixed substrate conditions, we next tested a six-member constructed community, which included both strains, to assess interactive effects amongst community members with different metabolic capabilities. Similar to the single strain experiments, concentration and source of the LOM addition interacted significantly to determine viable cell densities at each time point in the 14-day experiment (Figure 1 and Supplementary Table S8). For each source of LOM, the viable cell densities produced at $400 \mu \mathrm{M}-\mathrm{C}$ were significantly greater than those at lower LOM concentrations (three-way ANOVA, $n=5, p<0.001$ for all time points). For mixed NOM + LOM substrate experiments, the community demonstrated a synergistic growth response, for at least one time point, to all LOM sources at $400 \mu \mathrm{M}-\mathrm{C}$, and tryptone at $40 \mu \mathrm{M}-\mathrm{C}$ and $4 \mu \mathrm{M}-\mathrm{C}$ (Supplementary Figure S4 and Table 5). Though in some treatments (e.g., $4 \mu \mathrm{M}-\mathrm{C}$ tryptone and acetate and $400 \mu \mathrm{M}-\mathrm{C}$ casamino acids) this was preceded by an initial antagonistic interactive response. Relative to the $400 \mu \mathrm{M}$ concentrations, the community displayed a significant reduction in viable counts when supplied with each LOM source at $1 \mu \mathrm{M}-\mathrm{C}$; the intervening concentrations showed varying responses. The six-member constructed community was best

TABLE 4 | Probability values ${ }^{\mathrm{a}}$ for respiration interactive effects experimental data shown in Figures 2, 4.

\begin{tabular}{lcccc}
\hline \multicolumn{4}{c}{ LOM concentration $^{\boldsymbol{b}}$} \\
\cline { 2 - 5 } LOM source & $\mathbf{1} \boldsymbol{\mu} \mathbf{M}-\mathbf{C}$ & $\mathbf{4} \boldsymbol{\mu} \mathbf{M}-\mathbf{C}$ & $\mathbf{4 0} \boldsymbol{\mu} \mathbf{M}-\mathbf{C}$ & $\mathbf{4 0 0} \boldsymbol{\mu} \mathbf{M}-\mathbf{C}$ \\
\hline Acetate & Not measured & Not measured & Not measured & SE45: $p<0.30$ \\
& & & & E-37: $\boldsymbol{p}<\mathbf{0 . 0 0 1}$ \\
& & & Community: \\
& & & $p<0.50$ \\
Casamino acids & SE45: $\boldsymbol{p}<\mathbf{0 . 0 5}$ & SE45: $p<0.25$ & SE45: $p<0.45$ & SE45: $p<0.05$ \\
& E-37: $p<0.33$ & E-37: $p<0.35$ & E-37: $p<0.95$ & E-37: $\boldsymbol{p}<0.001$ \\
& Community: & Community: & Community: & Community: \\
Coumarate & $p<0.6$ & $p<0.33$ & $p<0.001$ & $p<0.60$ \\
& Not measured & Not measured & Not measured & SE45: $p<0.55$ \\
& & & E-37: $\boldsymbol{p}<0.001$ \\
& & & & Community: \\
& & & & $p<0.20$ \\
\hline
\end{tabular}

${ }^{a}$ Due to the unbalanced nature of the respirometer experimental design, two threeway ANOVAs were used to analyze the differences between mix and composite in terms of final $\mathrm{CO}_{2}$ accumulation. The two ANOVA models used tested whether the independent variables of inoculum, treatment, and either LOM source or concentration interacted to affect $\mathrm{CO}_{2}$ accumulation. As the $400 \mu \mathrm{M}-\mathrm{C}$ casamino acids data were analyzed in both ANOVAs, the higher of the two resulting p-value from the post hoc test were used to determine significance. $p$-values are adjusted to correct for the false discovery rate using the Benjamini-Hochberg correction. ${ }^{b} p$-values for synergistic interactive effects are bolded; $p$-values for antagonistic interactive effects are italicized.
TABLE 5 | Probability values ${ }^{a}$ for constructed community interactive effects experimental data shown in Figure $\mathbf{1}$

\begin{tabular}{|c|c|c|c|c|}
\hline \multirow[b]{2}{*}{ 2-5 LOM source } & \multicolumn{4}{|c|}{ LOM concentration $^{\mathrm{b}}$} \\
\hline & $1 \mu \mathrm{M}-\mathrm{C}$ & $4 \mu \mathrm{M}-\mathrm{C}$ & $40 \mu \mathrm{M}-\mathrm{C}$ & $400 \mu \mathrm{M}-\mathrm{C}$ \\
\hline \multirow[t]{2}{*}{ Acetate } & Days 1, 4, 7 & $\begin{array}{c}\text { Days } 1,10 \\
14\end{array}$ & Day 10 & Days $4,10,14$ \\
\hline & $p<0.05$ & $p<0.05$ & $p<0.01$ & $p<0.05$ \\
\hline \multirow[t]{2}{*}{ Casamino acids } & Days $1,2,4,7,10,14$ & $\begin{array}{l}\text { No significant } \\
\text { difference }\end{array}$ & Days 1, 14 & Day $4 p<0.01$ \\
\hline & $p<0.005$ & & $p<0.001$ & Day $10 p<0.01$ \\
\hline \multirow[t]{2}{*}{ Coumarate } & Days $1,2,7,10,14$ & $\begin{array}{l}\text { No significant } \\
\text { difference }\end{array}$ & $\begin{array}{l}\text { No significant } \\
\text { difference }\end{array}$ & Days 1,7 \\
\hline & $p<0.001$ & & & $p<0.001$ \\
\hline \multirow[t]{2}{*}{ Tryptone } & Days $1,2,7,10,14$ & Days 1,4 & Day 10 & Days 10, 14 \\
\hline & $p<0.001$ & $p<0.05$ & $p<0.001$ & $p<0.01$ \\
\hline
\end{tabular}

aFor each day, a three-way ANOVA was performed to determine whether differences in cell densities were being driven by treatment, concentration or source of LOM. p-values are adjusted to correct for the false discovery rate using the Benjamini Hochberg correction. ${ }^{b}$ Days listed are days in which there was a significant difference between the composite and mixed treatments. $p$-values for synergistic interactive effects are bolded and the corresponding table cell is shaded gray; $p$-values for antagonistic interactive effects are italicized.

able to utilize tryptone for growth; the three other LOM types reached cell densities $\sim 25 \%$ of tryptone-fed cultures (Figure 1). By day 14 , communities showed $\sim 60 \%$ decline in maximum viable cells on all of the substrates at $400 \mu \mathrm{M}$, except coumarate, for which there was $90 \%$ mortality (Figure 1).

No synergistic responses were observed in the constructed community when respiration was used as the measure of microbial activity. However, significant antagonistic responses were observed in the $40 \mu \mathrm{M}-\mathrm{C}$ casamino acids treatment (Table 4), as well as significantly lower $\mathrm{CO}_{2}$ production rates (1.5fold) compared to the LOM treatment (three-way ANOVA, $n=3$, $p<0.001$, Supplementary Tables S5-S7), corroborating some of the antagonistic results from the viable count-based approach used in the first experiment (see Figures 1, 4). $\mathrm{CO}_{2}$ production rates were 1.3- and 1.5-fold higher in the mixed treatments than the LOM alone treatments for the low concentrations ( 1 and 4 $\mu \mathrm{M}-\mathrm{C}$ ) of casamino acids treatments (three-way ANOVA, $n=3$, $p<0.001)$ and were statistically indistinguishable at the highest LOM concentrations (Supplementary Tables S5-S7).

\section{LOM Type Drives Microbial Community Composition}

We next assessed the influence of concentration and source of LOM on community composition in the six-member culture. Species diversity decreased with increasing LOM concentration in both single and mixed OM substrate treatments (Supplementary Figure S5). At the highest LOM concentration, mesocosms were dominated by a single strain: either SE45 on coumarate or Y4I on the other three LOM types (Figure 3). Treatment (mix or composite), LOM concentration, and LOM source interacted significantly to influence species diversity for all time points, with the exception of day 2 where only LOM concentration and source interacted significantly (three-way ANOVA, $n=5, p<0.002$ for all time points) (Supplementary Table S9). LOM concentration, LOM source, and treatment 


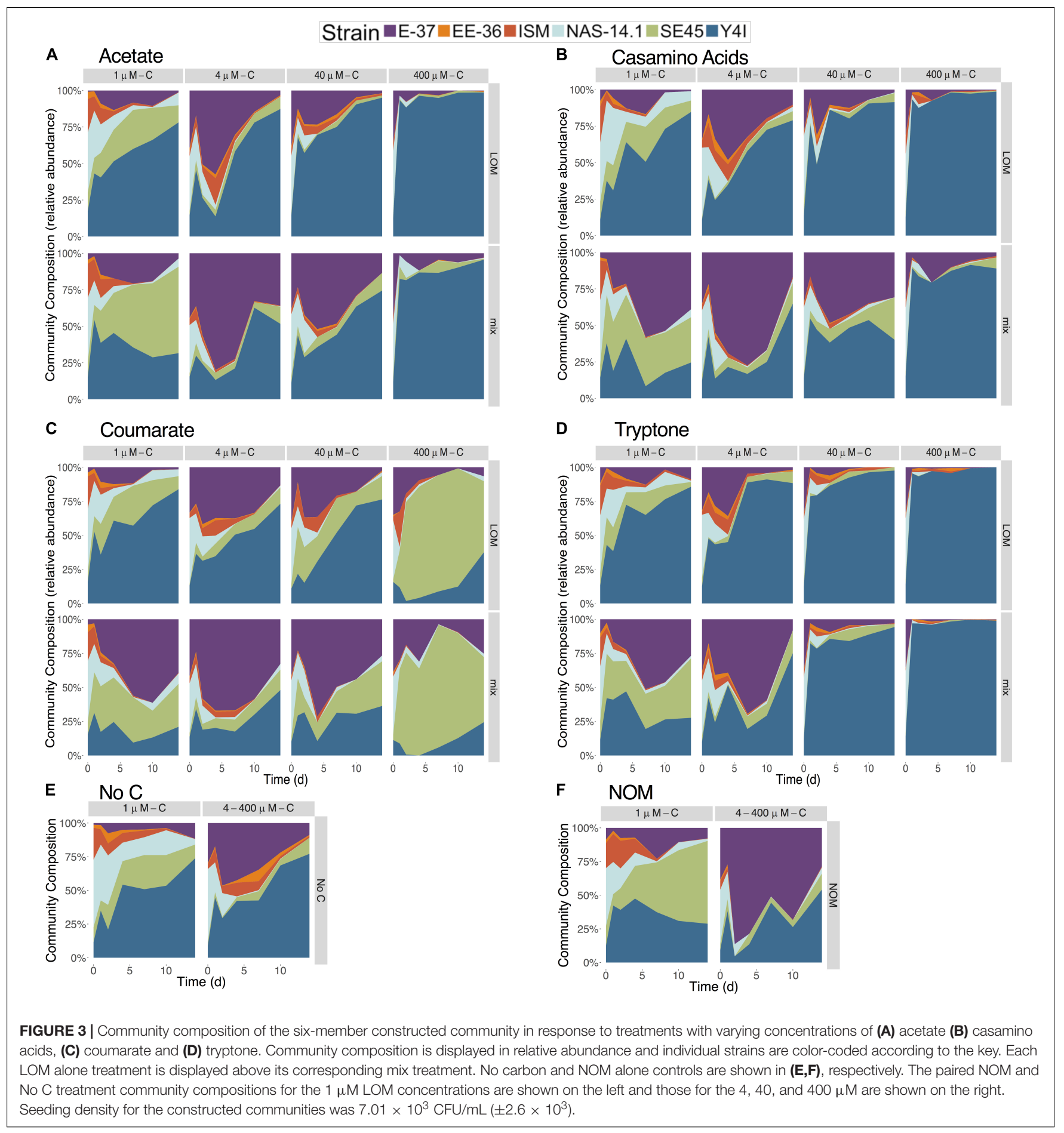

interacted significantly to drive differences between communities throughout the course of the incubation (permutational MANOVA, $p<0.05)$. Treatments using coumarate as LOM source resulted in a community distinct from the other sources of LOM at $400 \mu \mathrm{M}-\mathrm{C}$ (Figure 3). Coumarate communities were characterized by increased abundances of SE45, comprising up to $84-90 \%$ of the community, compared to the other sources of LOM, where communities were dominated by strain Y4I (up to $85-98 \%$ of the community) (Figure 3). Mixed LOM + NOM treatments had increased viable cell abundances for E-37 and SE45 compared to LOM alone treatments and both of these strains have increased viable cell densities in the NOM alone treatments compared to No C (Figures 1, 3). The community composition within the respirometer experiments generally mirrored that of the viable counts experiment in which Y4I was the most abundant member of the community for all 
sources of LOM, with the exception of the coumarate treatments (Supplementary Figure S6). The most notable difference between the community composition in the viable count vs. respirometer experiments is that Y4I maintained higher relative abundances at lower concentrations of LOM than in the viable counts (Supplementary Figure S6).

\section{DISCUSSION}

Traditionally, geochemical models designate $\mathrm{OM}$ as consisting of multiple, independent pools of compounds, each of which is degraded by microorganisms at different rates (Arndt et al., 2013; Hansell, 2013). However, recent findings in microbial physiology suggest that organic compounds can interact within microbial metabolisms in unpredictable ways (Gulvik and Buchan, 2013; Gontikaki et al., 2015; Ward et al., 2016). The degree to which OM interactivity in general, and the PE specifically, are quantitatively important in aquatic ecosystems is an area of current study and debate. Field and lab studies have shown that, depending on the precise circumstance, LOM can speed, slow, or have no effect on the oxidation of recalcitrant $\mathrm{OM}$ in aquatic environments (e.g., Gontikaki et al., 2013; Bengtsson et al., 2014; Bianchi et al., 2015; Catalán et al., 2015; Steen et al., 2016). Given these inconsistencies in the literature, we set out to perform controlled laboratory experiments to characterize interactive effects of distinct OM pools on microbial metabolism.

Coastal salt marsh microbial communities are subject to periodic pulses of OM from multiple sources and are inherently complex (e.g., Moran et al., 2007; Medeiros et al., 2017). Thus, the use of environmentally relevant and culturable representatives from these communities provides a tractable system for obtaining foundational knowledge of the underlying mechanisms of interactive effects on microbial processing of OM. Here, we used cultured representatives from a lineage of coastal marine bacteria that are known to dominate and be metabolically active in coastal estuaries (Buchan et al., 2005; Bakenhus et al., 2017). These bacteria were provided a natural and environmentally relevant source of recalcitrant OM, NOM derived from a river feeding Southeastern United States coastal estuaries. We assessed the microbial metabolic response to mixtures of labile and recalcitrant $\mathrm{OM}$ in two ways: by measuring viable cell abundance and by measuring $\mathrm{CO}_{2}$ production. These experiments revealed the importance of labile substrate concentration and chemical composition in dictating the growth dynamics of representative marine bacteria in the presence of NOM. We quantified speciesspecific responses to mixed substrate regimes, documented the transient nature of these responses and demonstrated microbial community composition shifts in response to interactive effects in relevant mixed carbon conditions.

\section{Interactive OM Effects Are Often Transient}

Our data with cultured bacteria demonstrate evidence of the transience of interactivity in $\mathrm{OM}$ degradation. These interactivities occurred on timeframes consistent with what has been reported previously in the PE literature for both individual microbial isolates and communities (1-7 days, e.g., D’Errico et al., 2013; Bianchi et al., 2015; Steen et al., 2016). Synergistic interactive effects of the labile and recalcitrant C sources on microbial growth were detectable either within the first few days of our incubations and/or as the microbial populations started to decline toward the end of the 14-day experimental period. With few exceptions, when synergistic interactions occurred, they did not persist beyond a 2- to 4-day timeframe. With some treatments, an additional, temporally distinct and positive synergistic interaction was observed 10-14 days into the experiment. Antagonistic interactive effects were also observed: for SE45 in half of the treatments conditions and $\sim 40 \%$ of the treatments for E-37 and the constructed community. These treatments were almost always at the lower concentrations of LOM, with the exception of E-37 when provided $400 \mu \mathrm{M}-\mathrm{C}$. While most of the antagonistic effects are transient, SE45 produces long-lasting antagonistic responses when provided NOM with $4 \mu \mathrm{M}-\mathrm{C}$ casamino acids and coumarate. E-37 demonstrated antagonistic effects lasting almost the entirety of the incubation when provided NOM along with $4 \mu \mathrm{M}$-C coumarate, and 4 or $400 \mu \mathrm{M}-\mathrm{C}$ tryptone. The constructed community displayed long antagonistic effects when provided $1 \mu \mathrm{M}-\mathrm{C}$ casamino acids, coumarate, and tryptone. Mix conditions containing acetate did not elicit long-lasting antagonistic effects. Instead, acetate appears to stimulate synergistic effects of the greatest duration in each inocula. This may indicate that, for Roseobacters, chemically simple labile substrates that feed directly into central metabolism are more likely to stimulate a synergistic effect at high concentrations, while more complex labile substrates may result in an antagonistic response at low concentrations.

While viable cell densities in treatments with NOM alone stayed relatively consistent throughout the incubation, most of the LOM only treatments exhibited severe declines in viable cell densities following an initial increase in cell growth. Those declines drove down the composite values used for comparisons with mix treatments to quantitatively assess interactive effects. The degree of viable cell demise tended to increased with increasing substrate concentration. Given the time scales of the experiments performed here, it is unlikely that substantial numbers of cells died as a result of lack of organic carbon or nutrients (Novitsky and Morita, 1978). Furthermore, the medium was well-buffered to prevent dramatic changes in $\mathrm{pH}$. However, it is plausible that the catabolism of a given LOM and/or NOM results in the production of toxic metabolic byproduct, giving rise to decreased viability. It has been previously shown that microbial conversion of simple carbon substrates can result in the production and release of a diversity of compounds (Lechtenfeld et al., 2015). Alternatively, prophage induction could have contributed to mortality. Three of the six strains, E-37, SE45, and Y4I, are predicated to encode prophage (Table 2), though to our knowledge induction of these prophages has not yet been demonstrated for any of these putative lysogens. Nonetheless, recent evidence suggests a correlation between bacterial productivity and lysogenic to lytic conversion in natural systems (Brum et al., 2016). Indeed, these two ideas are not mutually exclusive as increased bacterial metabolism could lead 
to enhanced production of toxic metabolic by-products that could, in turn, induce a global stress response in bacterial strains, initiating a lysogenic-lytic conversion (Feiner et al., 2015). Finally, growth substrate has been shown to influence prophage induction, indicating host metabolic state can have a direct influence on the lysogenic-lytic decision (e.g., Howes, 1965; Czyz et al., 2001).

Viable cell densities did not decline in the mixed treatments as precipitously as those in the LOM alone treatments. The apparent stabilizing effect seen in the mixed OM treatments compared to the composites may arise from the ability of the bacteria to access additional components of NOM, enabled by LOM catabolism, a mechanism posited by Guenet et al. (2010). Furthermore, in some instances, the cell densities in the mixed treatments begin to rebound toward the later stages of the experiment. The mixed carbon regime provided by the combination of LOM and NOM may yield conditions favorable for microbial adaptations, such as the proliferation of growth advantage in stationary phase (GASP) mutants (Zinser and Kolter, 1999), which could utilize previously unavailable components of the NOM, or possibly tolerate toxic compounds released by actively growing cells earlier in the incubation. Additional experiments are needed to specifically address the contribution of microbial adaptation, acclimation, prophage induction and metabolite toxicity to the observed trends.

Some inconsistencies between interactive effects in the viable counts and respiration data were observed and not completely unexpected. These discrepancies may indicate altered growth efficiencies under different substrate regimes. Alternatively, cultures had to remain static in the respirometer and it is plausible that biofilms developed under these conditions, though they were not visible to the naked eye. Roseobacters are prolific in natural marine biofilms (Dang and Lovell, 2000; Dang et al., 2008) and all six of these strains have been previously demonstrated to form biofilms when grown on complex media (Slightom and Buchan, 2009). The physiological status of bacteria growing in biofilms is different from those grown planktonically due to alterations in gene expression that can lead to changes in cell surface chemistry, physiology and behavior (Costerton et al., 1995). Thus, surface associated growth could influence microbial catabolism under mixed substrate regimes. Additional studies are needed to tease apart the contributions of these factors and we caution against making direct comparisons between the experiments that relied on viable counts (shown in Figures 1, 3) and those that monitored respiration (shown in Figures 2, 4).

\section{Interactive Effects Are Species-Specific}

While there is overlap between the mixed carbon substrate conditions that stimulate or repress growth of SE45, E-37 and the constructed community, each inoculum experienced $\mathrm{OM}$ interactivity under a unique set of conditions. For example, SE45 demonstrated a synergistic response to mixtures of NOM with $400 \mu \mathrm{M}-\mathrm{C}$ tryptone, a treatment in which E-37 responded antagonistically. The differential ability of SE45 and E-37 to undergo synergistic interactive effects through the addition of tryptone suggests that the expression and/or activity of extracellular enzymes could be an important factor in the onset of interactive effects. While monocultures of E-37 ultimately reach similar viable cell densities as all other members of the community, E-37 displays a considerably longer lag phase relative to the other strains when grown on $2 \mathrm{mM}-\mathrm{C}$ tryptone as a monoculture (Supplementary Figure S7). The delayed growth on tryptone may prevent E-37 from exhibiting a synergistic response with tryptone plus NOM when grown by itself. However, E-37 outperforms SE45 in the constructed community when provided low concentration of tryptone, which as discussed below, is indicative of synergistic interactions between community members. Both E-37 and SE45 undergo a synergistic interactive effect in the $40 \mu \mathrm{M}-\mathrm{C}$ acetate mixed treatment. However, the community undergoes an antagonistic interactive effect under the same conditions. It is plausible that competition with Y4I, the overwhelming dominant member of the community at high LOM concentrations of tryptone, casamino acids and acetate, contributes to the antagonistic effect seen in the constructed community treatments by preventing either E-37 or SE45 from performing necessary metabolic processes required for a synergistic response.

In agreement with our earlier report that a natural estuarine microbial community underwent a significant positive interactive effect with the addition of a globular protein (bovine serum albumin, provided at $500 \mu \mathrm{M}$ ) (Steen et al., 2016), the constructed community analyzed in this study displayed synergistic interactive effect in the presence of tryptone, an assortment of peptides, at $400 \mu \mathrm{M}$. However, timing of a response differed: it was delayed in the constructed community with tryptone (occurring during the second week of incubation) compared to an immediate priming response by the natural community provided complex protein. While there are many factors that could contribute to this apparent temporal disconnect, the relatively low strain diversity of the constructed community may be a key driver. By day 1, the constructed community was dominated by a single strain: Y4I comprised 98\% of the community in this treatment. Y4I belongs to the genus Phaeobacter, members of which were recently shown to bloom in the presence of Arctic riverine, dissolved OM (Sipler et al., 2017). Additionally, we earlier observed that acetate (at $500 \mu \mathrm{M}-\mathrm{C}$ ) repressed the ability of a estuarine microbial community to degrade phytoplankton necromass (Steen et al., 2016). However, in the current experiments all bacterial inocula demonstrated a synergistic growth response to the addition of acetate, at the highest concentration (400 $\mu \mathrm{M}-\mathrm{C}$ ). Collectively, these findings demonstrate that the substrate conditions that result in $\mathrm{OM}$ interactive effects are species-specific and thus dictated by the composition and metabolic potential of a community.

\section{Carbon Sources Shape the Composition and Diversity of the Constructed Community}

While scant information exists on how interactive effects influence community composition, studies that indicate riverine DOM structures the composition of microbial communities along the river-estuary continuum provide a useful comparative framework (Langenheder et al., 2004; Blanchet et al., 2017). 


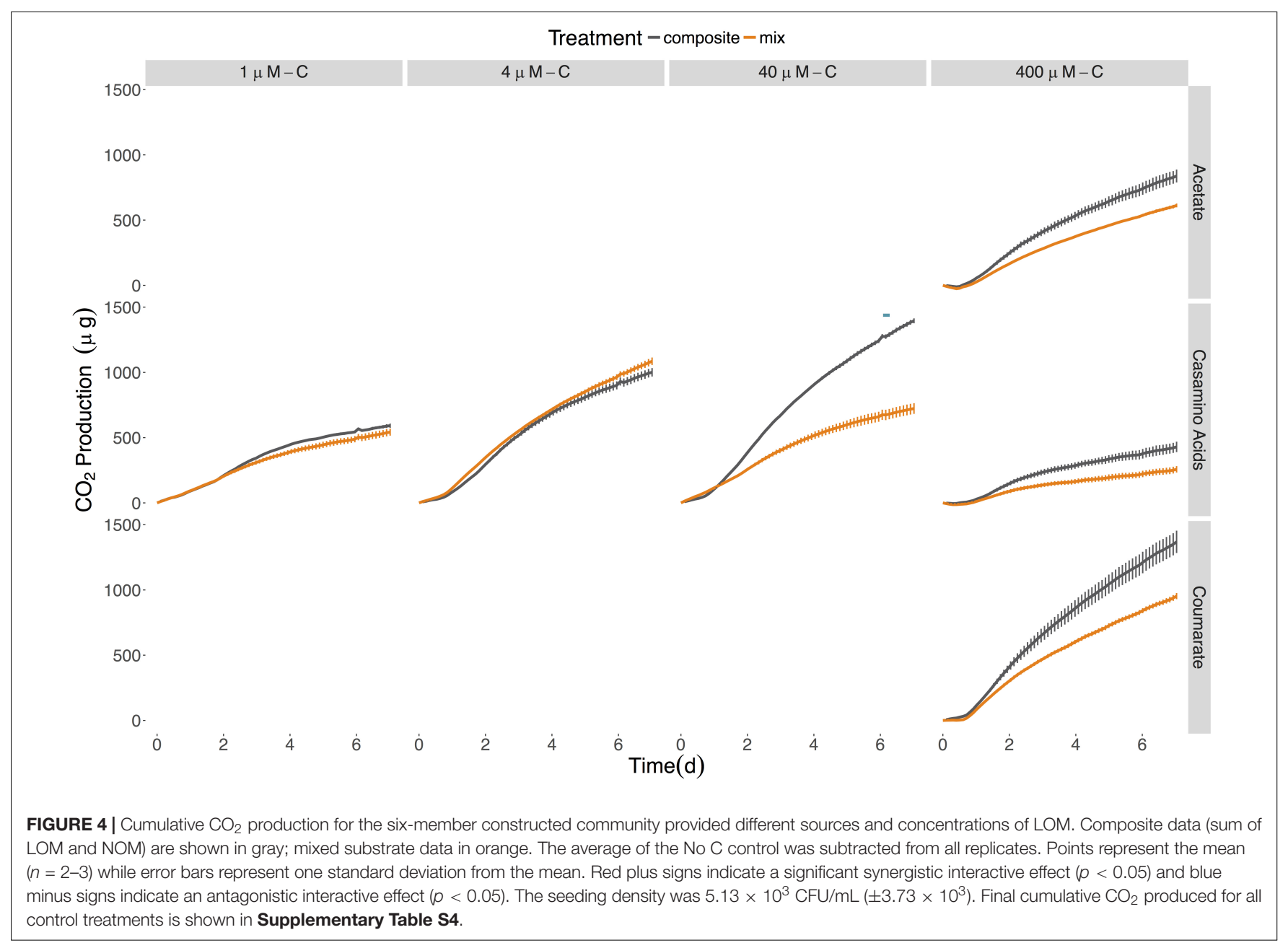

One report using an estuarine community incubated with riverine DOM and casamino acids saw no evidence for interactive effects and only minor alterations in microbial community composition (Blanchet et al., 2017). In contrast, we observed that the diversity of our constructed microbial community was influenced significantly both by the carbon sources present (e.g., LOM, NOM, or mixtures of the two) and the concentrations and sources of the LOM (Supplementary Table S9). E-37 has been previously shown to simultaneously catabolize aromatic compounds via two different ring cleaving pathways, the benzoyl Co-A and protocatechuate pathways, and derive a beneficial effect when grown on a mixture of carbon substrates compared to either substrate presented alone (Gulvik and Buchan, 2013). The metabolic synergy between these two aromatic carbon catabolism pathways may also be a mechanism for OM interactivities that has been previously overlooked.

Our studies reveal that structure of the constructed communities may often be determined by the concentration of LOM provided, regardless of chemical form. With the exception of the highest coumarate concentration treatment, a general trend emerged: as the concentration of LOM increases, the diversity within the constructed community decreases. This stands in contrast to some prior studies in which increasing amounts of autochthonous carbon resulted in increased degradation of allochthonous carbon, with little to no effect on bacterial community composition (Attermeyer et al., 2014). This decrease in diversity was most pronounced in the highest LOM additions (400 $\mu \mathrm{M}-\mathrm{C})$, where a single strain (Y4I) dominated all, but the coumarate, treatments. The shorter lag phase and faster growth rate of Y4I relative to other members of the community when grown on labile substrates may have allowed Y4I to gain an early foothold in the community. This possibility is supported by the fact that the numerical dominance of Y4I began as early as day 1 in the incubations, after which it either increased in terms of relative abundance or maintained its numerical dominance in the community (Figure 3). The stark contrast in community composition between those cultures provided coumarate compared to the other LOM types is likely due to the unique ability of SE45 and E-37 to utilize coumarate as a carbon source. For the coumarate treatments, SE45, and to a lesser extent E-37, become the most numerically abundant organisms. Given that these strains are both ligninolytic they are likely better tuned to access the aromatic carbon moieties characteristic of NOM (Gonzalez et al., 1997; Frank, 2016).

Cooperation and competition may be important ecological processes influencing the outcome of interactive effects 
(Fontaine et al., 2003). Our data indicate both cooperation and competition under different conditions in the constructed community experiments. For example, SE45 reached higher cell densities in the constructed community in the presence of both NOM and $400 \mu \mathrm{M}-\mathrm{C}$ coumarate compared to its growth on these substrates in monoculture. Additionally, E-37 growth is enhanced in the constructed community when provided low concentrations of tryptone compared to monocultures. This strain may gain an advantage from other members of the community that produce extracellular peptidases, liberating free amino acids that E-37 is, in turn, more competitive at transporting and catabolizing. While many bacteria can transport the lower molecular weight fraction of tryptone directly into cells via oligopeptide permeases (Garault et al., 2002), up to $10 \%$ of tryptone is between 2 and $5 \mathrm{kDa}$ (BD Biosciences, 2006) and requires initial cleavage by extracellular peptidases. Extracellular enzymes are generally considered "public goods" because they may provide benefit to the community, while being costly for individuals to produce. Individuals within a community who take advantage of public goods without producing them are termed cheaters and cheating has been shown to increase in frequency in well-mixed systems with high diffusion rates (Allison et al., 2014), such as the culture conditions employed in this study.

In coastal marshes, the DOC pool is highly heterogenous in both structure and distribution. Similarly, the microbial communities in these systems display a high degree of genetic and functional diversity and are patchy in both their abundances and activity. Deciphering the complex chemical and biological interactions that unlike the mineralization of organic carbon in these systems is a daunting challenge. Yet, a detailed understanding of the nature and sources of LOM to estuaries, as well as

\section{REFERENCES}

Alberts, J. J., and Takács, M. (1999). Importance of humic substances for carbon and nitrogen transport into southeastern United States estuaries. Org. Geochem. 30, 385-395. doi: 10.1016/S0146-6380(99)00024-8

Allison, S. D., Lu, L., Kent, A. G., and Martiny, A. C. (2014). Extracellular enzyme production and cheating in Pseudomonas fluorescens depend on diffusion rates. Front. Microbiol. 5:169. doi: 10.3389/fmicb.2014.00169

Arndt, S., Jørgensen, B. B., LaRowe, D. E., Middelburg, J. J., Pancost, R. D., and Regnier, P. (2013). Quantifying the degradation of organic matter in marine sediments: a review and synthesis. Earth Sci. Rev. 123, 53-86. doi: 10.1016/j. earscirev.2013.02.008

Attermeyer, K., Hornick, T., Kayler, Z. E., Bahr, A., Zwirnmann, E., Grossart, H.P., et al. (2014). Enhanced bacterial decomposition with increasing addition of autochthonous to allochthonous carbon without any effect on bacterial community composition. Biogeosciences 11, 1479-1489. doi: 10.5194/bg-111479-2014

Bakenhus, I., Dlugosch, L., Billerbeck, S., Giebel, H. A., Milke, F., and Simon, M. (2017). Composition of total and cell-proliferating bacterioplankton community in early summer in the North Sea - roseobacters are the most active component. Front. Microbiol. 8:1171. doi: 10.3389/fmicb.2017.01771

BD Biosciences (2006). BD Bionutrients TM Technical Manual - Advanced Bioprocessing. Franklin Lakes, NJ: BD Biosciences, 1-72.

Bengtsson, M. M., Attermeyer, K., and Catalán, N. (2018). Interactive effects on organic matter processing from soils to the ocean: are priming effects relevant in aquatic ecosystems? Hydrobiologia 882, 1-17. doi: 10.1007/s10750-018-3672-2 the molecular mechanisms driving interactive effects, will be necessary to understand the controls on microbial oxidation of terrestrial organic carbon in estuaries. In order to elucidate microbe-multi-substrate interactivities, controlled laboratory experiments employing relatively low chemical and biological complexity provide an important foundation on which to build.

\section{AUTHOR CONTRIBUTIONS}

$L Q$, $A S$, and $A B$ designed the experiments and drafted the manuscript. LQ and AE performed the experiments. LQ analyzed the data.

\section{FUNDING}

This research was supported by a grant from the National Science Foundation (OCE-1357242) awarded to AB and AS.

\section{ACKNOWLEDGMENTS}

We thank Terry Hazen for the use of the respirometer and Melanie Mayes and Hannah Woo for training on the instrument.

\section{SUPPLEMENTARY MATERIAL}

The Supplementary Material for this article can be found online at: https://www.frontiersin.org/articles/10.3389/fmicb. 2019.00493/full\#supplementary-material

Bengtsson, M. M., Wagner, K., Burns, N. R., Herberg, E. R., Wanek, W., Kaplan, L. A., et al. (2014). No evidence of aquatic priming effects in hyporheic zone microcosms. Sci. Rep. 4:5187. doi: 10.1038/srep05187

Benjamini, Y., and Hochberg, Y. (1995). Controlling the false discovery rate: a practical and powerful approach to multiple testing. J. R. Stat. Soc. 57, 289-300. doi: 10.2307/2346101

Bianchi, T. S. (2011). The role of terrestrially derived organic carbon in the coastal ocean: a changing paradigm and the priming effect. Proc. Natl. Acad. Sci. U.S.A. 108, 19473-19481. doi: 10.1073/pnas.1017982108

Bianchi, T. S., Thornton, D. C. O., Yvon-Lewis, S. A., King, G. M., Eglinton, T. I., Shields, M. R., et al. (2015). Positive priming of terrestrially derived dissolved organic matter in a freshwater microcosm system. Geophys. Res. Lett. 42, 5460-5467. doi: 10.1002/2015GL064765

Blagodatskaya, E., and Kuzyakov, Y. (2008). Mechanisms of real and apparent priming effects and their dependence on soil microbial biomass and community structure: critical review. Biol. Fertil. Soils 45, 115-131. doi: 10.1007/s00374008-0334-y

Blanchet, M., Pringault, O., Panagiotopoulos, C., Lefèvre, D., Charrière, B., Ghiglione, J. F., et al. (2017). When riverine dissolved organic matter (DOM) meets labile DOM in coastal waters: changes in bacterial community activity and composition. Aquat. Sci. 79, 27-43. doi: 10.1007/s00027-0160477-0

Brum, J. R., Hurwitz, B. L., Schofield, O., Ducklow, H. W., and Sullivan, M. B. (2016). Seasonal time bombs: dominant temperate viruses affect southern ocean microbial dynamics. ISME J. 10, 437-449. doi: 10.1038/ismej. 2015.125 
Buchan, A., and González, J. M. (2010). "Roseobacter," in Handbook of Hydrocarbon and Lipid Microbiology, eds K. N. Timmis, T. J. McGenity, J. R. van der Meer, and V. de Lorenzo (Berlin: Springer), 1335-1343. doi: 10.1007/ 978-3-540-77587-4_93

Buchan, A., Collier, L. S., Neidle, E. L., and Moran, M. A. (2000). Key aromaticring-cleaving enzyme, protocatechuate 3,4-dioxygenase, in the ecologically important marine roseobacter lineage. Appl. Environ. Microbiol. 66, 4662-4672. doi: 10.1128/AEM.66.11.4662-4672.2000

Buchan, A., González, J. M., and Moran, M. A. (2005). Overview of the marine roseobacter lineage. Appl. Environ. Microbiol. 71, 5665-5677. doi: 10.1128/ AEM.71.10.5665-5677.2005

Catalán, N., Kellerman, A. M., Peter, H., Carmona, F., and Tranvik, L. J. (2015). Absence of a priming effect on dissolved organic carbon degradation in lake water. Limnol. Oceanogr. 60, 159-168. doi: 10.1002/lno.10016

Chua, M. (2018). Genomic and Physiological Characterization of Lignin-Derived Aromatic Catabolism Pathways in Roseobacters. Dissertation. Knoxville, TN: University of Tennessee.

Costerton, J. W., Lewandowski, Z., Caldwell, D. E., Korber, D. R., and LappinScott, H. M. (1995). Microbial biofilms. Annu. Rev. Microbiol. 49, 711-745. doi: 10.1146/annurev.mi.49.100195.003431

Cude, W. N., Mooney, J., Tavanaei, A. A., Hadden, M. K., Frank, A. M., Gulvik, C. A., et al. (2012). Production of the antimicrobial secondary metabolite indigoidine contributes to competitive surface colonization by the marine roseobacter Phaeobacter sp. strain Y4I. Appl. Environ. Microbiol. 78, 4771-4780. doi: 10.1128/AEM.00297-12

Czyz, A., Los, M., Wrobel, B., and Wegrzyn, G. (2001). Inhibition of spontaneous induction of lambdoid prophages in Escherichia coli cultures: simple procedures with possible biotechnological applications. BMC Biotechnol. 1:1. doi: 10.1186/ 1472-6750-1-1

Dal, S., Steiner, I., and Gerischer, U. (2002). Multiple operons connected with catabolism of aromatic compounds in Acinetobacter sp. strain ADP1 are under carbon catabolite repression. J. Mol. Microbiol. Biotechnol. 4, 389-404.

Dang, H., Li, T., Chen, M., and Huang, G. (2008). Cross-ocean distribution of Rhodobacterales bacteria as primary surface colonizers in temperate coastal marine waters. Appl. Environ. Microbiol. 74, 52-60. doi: 10.1128/AEM. 01400-07

Dang, H., and Lovell, C. R. (2000). Bacterial primary colonization and early succession on surfaces in marine waters as determined by amplified rRNA gene restriction analysis and sequence analysis of $16 \mathrm{~S}$ rRNA genes. Appl. Environ. Microbiol. 66, 467-475. doi: 10.1128/AEM.66.2.467-475.2000

D’Errico, G., Giovannelli, D., Montano, C., Milanovic, V., Ciani, M., and Manini, E. (2013). Bioremediation of high organic load lagoon sediments: compost addition and priming effects. Chemosphere 91, 99-104. doi: 10.1016/j. chemosphere.2012.11.037

Feiner, R., Argov, T., Rabinovich, L., Sigal, N., Borovok, I., and Herskovits, A. A. (2015). A new perspective on lysogeny: prophages as active regulatory switches of bacteria. Nat. Rev. Microbiol. 13, 641-650. doi: 10.1038/nrmicro3527

Fontaine, S., Mariotti, A., and Abbadie, L. (2003). The priming effect of organic matter: a question of microbial competition? Soil Biol. Biochem. 35, 837-843. doi: 10.1016/S0038-0717(03)00123-8

Frank, A. M. (2016). Aerobic Bacterial Transformations of Lignin-Derived Aromatic Compounds. Doctoral Dissertation, University of Tennessee, Knoxville.

Garault, P., Le Bars, D., Besset, C., and Monnet, V. (2002). Three oligopeptide-binding proteins are involved in the oligopeptide transport of Streptococcus thermophilus. J. Biol. Chem. 277, 32-39. doi: 10.1074/jbc.M107 002200

Gontikaki, E., Thornton, B., Cornulier, T., and Witte, U. (2015). Occurrence of priming in the degradation of lignocellulose in marine sediments. PLoS One 10:e0143917. doi: 10.1371/journal.pone.0143917

Gontikaki, E., Thornton, B., Huvenne, V. A. I., Witte, U., and Abbadie, L. (2013). Negative priming effect on organic matter mineralisation in NE atlantic slope sediments. PLoS One 8:e67722. doi: 10.1371/journal.pone. 0067722

González, J. M., Kiene, R. P., and Moran, M. A. (1999). Transformation of sulfur compounds by an abundant lineage of marine bacteria in the $\alpha$-subclass of the class Proteobacteria. Appl. Environ. Microbiol. 65, 3810-3819.

Gonzalez, J. M., Mayer, F., Moran, M. A., Hodson, R. E., and Whitman, W. B. (1997). Sagittula stellata gen. nov., sp. nov., a lignin-transforming bacterium from a coastal environment. Int. J. Syst. Bacteriol. 47, 773-780. doi: 10.1099/ 00207713-47-3-773

Guenet, B., Danger, M., Abbadie, L., and Lacroix, G. (2010). Priming effect: bridging the gap between terrestrial and aquatic ecology. Ecology 91, 2850-2861. doi: 10.1890/09-1968.1

Gulvik, C. A., and Buchan, A. (2013). Simultaneous catabolism of plantderived aromatic compounds Results in enhanced growth for members of the roseobacter lineage. Appl. Environ. Microbiol. 79, 3716-3723. doi: 10.1128/ AEM.00405-13

Hansell, D. A. (2013). Recalcitrant dissolved organic carbon fractions. Ann. Rev. Mar. Sci. 5, 421-445. doi: 10.1146/annurev-marine-120710-100757

Hedges, J. I., Blanchette, R. A., Weliky, K., and Devol, A. H. (1988). Effects of fungal degradation on the $\mathrm{CuO}$ oxidation products of lignin: a controlled laboratory study. Geochim. Cosmochim. Acta 52, 2717-2726. doi: 10.1016/0016-7037(88) 90040-3

Hedges, J. I., Keil, R. G., and Benner, R. (1997). What happens to terrestrial organic matter in the ocean? Org. Geochem. 267, 195-212. doi: 10.1016/S0146-6380(97) 00066- 1

Her, N., Amy, G., McKnight, D., Sohn, J., and Yoon, Y. (2003). Characterization of DOM as a function of MW by fluorescence EEM and HPLC-SEC using UVA, DOC, and fluorescence detection. Water Res. 37, 4295-4303. doi: 10.1016/ S0043-1354(03)00317-8

Howes, W. V. (1965). Effect of glucose on the capacity of Escherichia coli to be infected by a virulent lamba bacteriophage. J. Bacteriol. 90, 1188-1193.

Hyndes, G. A., Nagelkerken, I., Mcleod, R. J., Connolly, R. M., Lavery, P. S., and Vanderklift, M. A. (2014). Mechanisms and ecological role of carbon transfer within coastal seascapes. Biol. Rev. 89, 232-254. doi: 10.1111/brv.12055

Jenkinson, D. S., Fox, R. H., and Rayner, J. H. (1985). Interactions between fertilizer nitrogen and soil nitrogen-the so-called 'priming' effect. J. Soil Sci. 36, 425-444. doi: 10.1111/j.1365-2389.1985.tb00348.x

Jost, L. (2007). Partitioning diversity into independent alpha and beta components. Ecology 88, 2427-2439. doi: 10.1890/06-1736.1

Kuzyakov, Y., Friedel, J. K., and Stahr, K. (2000). Review of mechanisms and quantification of priming effects. Soil Biol. Biochem. 32, 1485-1498. doi: 10. 1016/S0038-0717(00)00084-5

Langenheder, S., Kisand, V., Lindström, E. S., Wikner, J., and Tranvik, L. J. (2004). Growth dynamics within bacterial communities in riverine and estuarine batch cultures. Aquat. Microb. Ecol. 37, 137-148. doi: 10.3354/ame037137

Lechtenfeld, O. J., Hertkorn, N., Shen, Y., Witt, M., and Benner, R. (2015). Marine sequestration of carbon in bacterial metabolites. Nat. Commun. 6:6711. doi: 10.1038 /ncomms7711

Mannino, A., and Harvey, H. R. (2000). Terrigenous dissolved organic matter along an estuarine gradient and its flux to the coastal ocean. Org. Geochem. 31, 1611-1625. doi: 10.1016/S0146-6380(00)00099-1

Mazzoli, R., Pessione, E., Giuffrida, M. G., Fattori, P., Barello, C., Giunta, C., et al. (2007). Degradation of aromatic compounds by Acinetobacter radioresistens S13: growth characteristics on single substrates and mixtures. Arch. Microbiol. 188, 55-68. doi: 10.1007/s00203-007-0223-z

Medeiros, P. M., Seidel, M., Gifford, S. M., Ballantyne, F., Dittmar, T., Whitman, W. B., et al. (2017). Microbially-mediated transformations of estuarine dissolved organic matter. Front. Mar. Sci. 4:69. doi: 10.3389/fmars.2017.00069

Moran, M. A., Belas, R., Schell, M. A., González, J. M., Sun, F., Sun, S., et al. (2007). Ecological genomics of marine roseobacters. Appl. Environ. Microbiol. 73, 4559-4569. doi: 10.1128/AEM.02580-06

Mou, X., Sun, S., Edwards, R. A., Hodson, R. E., and Moran, M. A. (2008). Bacterial carbon processing by generalist species in the coastal ocean. Nature 451, 708-711. doi: 10.1038/nature06513

Newton, R. J., Griffin, L. E., Bowles, K. M., Meile, C., Gifford, S., Givens, C. E., et al. (2010). Genome characteristics of a generalist marine bacterial lineage. ISME J. 4, 784-798. doi: 10.1038/ismej.2009.150

Novitsky, J. A., and Morita, R. Y. (1978). Possible strategy for the survival of marine bacteria under starvation conditions. Mar. Biol. 48, 289-295. doi: 10. 1007/BF00397156

Oksanen, J., Blanchet, F. G., Kindt, R., Legendre, P., Minchin, P. R., O’Hara, R. B., et al. (2017). vegan: Community Ecology Package. $R$ Packag. ver. 2.4-3. doi: 10.4135/9781412971874.n145

Osburn, C. L., Boyd, T. J., Montgomery, M. T., Bianchi, T. S., Coffin, R. B., and Paerl, H. W. (2016). Optical proxies for terrestrial dissolved organic matter in 
estuaries and coastal waters. Front. Mar. Sci. 2:127. doi: 10.3389/fmars.2015. 00127

R Core team (2015). R Core Team. A Language and Environment for Statistical Computing. Vienna: R Foundation for Statistical Computing.

Roux, S., Enault, F., Hurwitz, B. L., and Sullivan, M. B. (2015). VirSorter: mining viral signal from microbial genomic data. PeerJ 3:e985. doi: 10.7717/ peerj.985

Sipler, R. E., Kellogg, C. T. E., Connelly, T. L., Roberts, Q. N., Yager, P. L., and Bronk, D. A. (2017). Microbial community response to terrestrially derived dissolved organic matter in the coastal arctic. Front. Microbiol. 8:1018. doi: 10.3389/fmicb.2017.01018

Slightom, R. N., and Buchan, A. (2009). Surface colonization by marine roseobacters: integrating genotype and phenotype. Appl. Environ. Microbiol. 75, 6027-6037. doi: 10.1128/AEM.01508-09

Steen, A. D., Quigley, L. N., and Buchan, A. (2016). Evidence for the priming effect in a planktonic estuarine microbial community andrew. Front. Mar. Sci. 3:6. doi: 10.3389/fmars.2016.00006

Sun, L., Perdue, E. M., Meyer, J. L., and Weis, J. (1997). Use of elemental composition to predict bioavailability of dissolved organic matter in a Georgia river. Limnol. Oceanogr. 42, 714-721. doi: 10.4319/lo.1997.42.4.0714

Vannote, R. L., Minshall, G. W., Cummins, K. W., Sedell, J. R., and Cushing, C. E. (1980). The river continuum concept. Can. J. Fish. Aquat. Sci. 37, 130-137. doi: 10.1139/f80-017

Ward, N. D., Bianchi, T. S., Sawakuchi, H. O., Gagne-Maynard, W., Cunha, A. C., Brito, D. C., et al. (2016). The reactivity of plant-derived organic matter and the potential importance of priming effects along the lower Amazon River. J. Geophys. Res. Biogeosci. 121, 1522-1539. doi: 10.1002/2016JG003342

Ward, N. D., Keil, R. G., Medeiros, P. M., Brito, D. C., Cunha, A. C., Dittmar, T., et al. (2013). Degradation of terrestrially derived macromolecules in the Amazon River. Nat. Geosci. 6:1817. doi: 10.1038/ngeo 1817

Wickham, H. (2009). ggplot2: Elegant Graphics for data Analysis. New York, NY: Springer Science, doi: 10.1007/978-0-387-98141-3

Wiegart, R. G., and Freeman, B. J. (1990). Tidal marshes of the southeastern Atlantic coast: a community profile. U.S. Fish Wildl. Serv. 85, 1-80. doi: 10.1017/ CBO9781107415324.004

Zinser, E. R., and Kolter, R. (1999). Mutations enhancing amino acid catabolism confer a growth advantage in stationary phase. J. Bacteriol. 181, 5800-5807.

Conflict of Interest Statement: The authors declare that the research was conducted in the absence of any commercial or financial relationships that could be construed as a potential conflict of interest.

Copyright (c) 2019 Quigley, Edwards, Steen and Buchan. This is an open-access article distributed under the terms of the Creative Commons Attribution License (CC BY). The use, distribution or reproduction in other forums is permitted, provided the original author(s) and the copyright owner(s) are credited and that the original publication in this journal is cited, in accordance with accepted academic practice. No use, distribution or reproduction is permitted which does not comply with these terms. 